\title{
Temporal and Spatial Distribution Patterns of Potentially Pathogenic Vibrio spp. at Recreational Beaches of the German North Sea
}

\author{
Simone I. Böer • Ernst-August Heinemeyer • \\ Katrin Luden • René Erler • Gunnar Gerdts • \\ Frank Janssen • Nicole Brennholt
}

Received: 11 December 2012 / Accepted: 14 March 2013 / Published online: 7 April 2013

(C) Springer Science+Business Media New York 2013

\begin{abstract}
The number of reported Vibrio-related wound infections associated with recreational bathing in Northern Europe has increased within the last decades. In order to study the health risk from potentially pathogenic Vibrio spp. in the central Wadden Sea, the seasonal and spatial distribution of Vibrio vulnificus, Vibrio parahaemolyticus, Vibrio alginolyticus and Vibrio cholerae were investigated at ten recreational beaches in this area over a 2-year period. V. alginolyticus and $V$. parahaemolyticus were found to be omnipresent all year round in the study area, while $V$. vulnificus occurrence was restricted to summer months in the estuaries of the rivers Ems and Weser. Multiple linear regression models revealed
\end{abstract}

Electronic supplementary material The online version of this article (doi:10.1007/s00248-013-0221-4) contains supplementary material, which is available to authorized users.

S. I. Böer $(\bowtie) \cdot N$. Brennholt

Department G3-Bio-Chemistry, Ecotoxicology, Federal Institute of Hydrology, Am Mainzer Tor 1,

56068 Koblenz, Germany

e-mail: Boeer@bafg.de

E.-A. Heinemeyer $\cdot$ K. Luden

Governmental Institute for Public Health of Lower Saxony,

Lüchtenburger Weg 24,

26603 Aurich, Germany

R. Erler $\cdot$ G. Gerdts

Biological Institute Helgoland, Division of Shelf Seas Systems

Ecology, Alfred Wegener Institute for Polar and Marine Research,

Kurpromenade,

27498 Helgoland, Germany

F. Janssen

Federal Maritime and Hydrographic Agency,

Bernhard-Nocht-Str. 78,

20359 Hamburg, Germany that water temperature is the most important determinant of Vibrio spp. occurrence in the area. Differentiated regression models showed a species-specific response to water temperature and revealed a particularly strong effect of even minor temperature increases on the probability of detecting $V$. vulnificus in summer. In sediments, Vibrio spp. concentrations were up to three orders of magnitude higher than in water. Also, V. alginolyticus and V. parahaemolyticus were found to be less susceptible towards winter temperatures in the benthic environment than in the water, indicating an important role of sediments for Vibrio ecology. While only a very small percentage of tested $V$. parahaemolyticus proved to be potentially pathogenic, the presence of $V$. vulnificus during the summer months should be regarded with care.

\section{Introduction}

Vibrionaceae constitute an important family within the Gammaproteobacteria and are common natural members of marine and estuarine bacterial plankton communities. At least 12 species of the Vibrio genus are potentially pathogenic to humans [1]. Particularly Vibrio parahaemolyticus and Vibrio vulnificus, but also Vibrio alginolyticus and Vibrio cholerae are known as causative agents of seawater-related illnesses, such as seafood poisoning in association with gastrointestinal infections [2-4] and infections of wounds and mucous membranes [5-11].

A strong link between water temperature and the number of Vibrio spp. in seawater or shellfish and the frequency of occurrence of Vibrio incidences has been discovered in a vast range of studies in a number of regions (e.g. [12-17]). This link was assigned both to direct temperature effects as 
well as to indirect effects by planktonic food-web interactions $[18,19]$. For temperate Northern European Waters, an increasing number of seawater-related wound infections have been reported since the mid-1990s, mainly during summer heat waves. The majority of these infections occurred at the Baltic Sea coast such as in Denmark [20, 21], Sweden [5, 22], Finland [23] and Germany [24]; however, sporadic Vibriorelated cases were recorded upon contact with North Sea waters in the Netherlands [9, 25] and Britain [26].

An increasing number of studies accumulate evidence of an emerging risk of Vibrio-related wound infections in high latitudes as a consequence of climate anomalies such as temporal peaks in sea surface temperatures [27]. Due to its semi-enclosed character, the North Sea is one of the seas most vulnerable towards such ocean warming trends [28]. Mean sea surface temperatures in the North Sea have increased two to four times faster than average, more than $1.3{ }^{\circ} \mathrm{C}$ in the last decades [28-30]. The probability of extreme summers and years has more than doubled simultaneously [29], both of which could support the spreading of potentially pathogenic vibrios in this region. Investigations recently showed that Vibrio spp. numbers, including potential pathogens, have increased within the plankton-associated bacterial community of the North Sea during the last half century [31].

The increasing number of bathing water-related infections in the Northern European seas in recent years concerned scientists, and a number of studies have been conducted in order to gain a better understanding of Vibrio occurrence and ecology in these waters (e.g. [17, 32-37]). Early work has provided an indication of the presence of potentially pathogenic Vibrio species at the German North Sea coast [38]; however, the ecology of these organisms has not been studied in depth for these waters. The present study is aimed at elucidating the seasonal and spatial distribution of potentially pathogenic Vibrio spp. in the central Wadden Sea and within the estuaries of the rivers Ems and Weser for the first time. V. vulnificus, $V$. parahaemolyticus, $V$. alginolyticus and $V$. cholerae were quantified monthly at ten recreational beaches over a 2-year period in relation to environmental conditions, using a culturing approach. Species identification was verified via molecular biological testing for speciesspecific gene targets in a number of isolates. The pathogenicity of representative $V$. parahaemolyticus and $V$. cholerae isolates was further investigated via biochemical and molecular biological tests. Since most documented cases in Germany were associated with $V$. vulnificus, special focus was given to this organism. The main research questions were: (1) Do V. vulnificus and other potentially pathogenic Vibrio species occur in this area and are there species-specific distribution patterns? (2) What are the main environmental drivers shaping the Vibrio community in the area? (3) Are there species-specific responses to environmental drivers such as water temperature and salinity? (4) Are virulent strains of V.parahaemolyticus and $V$. cholerae part of the Vibrio community in this region? Sediment samples were examined in addition to water samples in order to give a more comprehensive insight into Vibrio ecology. Although attachment to sediments and particles has been shown to be one of the survival strategies of Vibrio spp. (e.g. [15]), few environmental studies have considered the sedimentary matrix (e.g. [39, 40]), thus neglecting an important component with regard to the assessment of possible health risks.

\section{Material and Methods}

\section{Study Area and Sampling}

Ten beaches (eight designated and two non-designated beaches) along the Central Wadden Sea coast and within the estuaries of the rivers Ems and Weser were tested for the occurrence of potentially pathogenic Vibrio species. The sites comprise all types of coastal waters according to the classification of the EU Water Framework Directive with the exception of the euhaline Wadden Sea type (Table 1, Fig. 1).

Water and sediment samples were taken monthly between December 2009 and December 2011 by staff of the local health authorities. Some winter samples could not be taken because of ice formation; one March sample had to be removed from analysis because the sample containers were not adequately labelled (Table 1). Water samples were taken according to ISO 19458 [41]. Surface sediments were sampled aseptically either directly with the sample containers or with sterile sampling devices and decanted afterwards, depending on submergence of the sediments. Water temperature was measured in situ with portable $\mathrm{pH}$ meters (Dyksterhusen, Borkum: Hach Lange, type HQ11d; Norderney, Norddeich: Hach Lange, type HQ30d; Duhnen, Dorum, Wremen: WTW, type ProfiLine $\mathrm{pH}$ 3110; Dedesdorf, Bremerhaven, Burhave: VOLTCRAFT $300 \mathrm{~K}$ ). Samples were transported to the laboratory in Aurich within 3-4 h and processed immediately upon arrival. Since cold temperatures impact $V$. vulnificus, while high temperatures may promote growth of the organism, samples were only chilled during transport on hot summer days, avoiding direct contact with cool packs.

\section{Vibrio spp. Analyses}

For the detection of Vibrio spp. in the water samples, two methods were used. Sample volumes of $0.1 \mathrm{~mL}$ up to $100 \mathrm{~mL}$ were membrane filtered (Whatman, ME 25/21 STL, pore size $0.45 \mu \mathrm{m}$ ), depending on the number of colonies expected based on water temperature and experience from preceding months. Filtration of volumes $<10 \mathrm{~mL}$ was augmented by the addition of a sterile $\mathrm{NaCl}$ solution 
Table 1 Overview over the sampling sites and sampling schemes

\begin{tabular}{|c|c|c|c|c|c|c|c|}
\hline \multirow[t]{2}{*}{ Site } & \multicolumn{2}{|c|}{ Coordinates } & \multirow[t]{2}{*}{ Classification (coastal waters) } & \multirow{2}{*}{$\begin{array}{l}\text { Time of } \\
\text { sampling }\end{array}$} & \multirow[t]{2}{*}{ Bathing water quality ${ }^{\mathrm{a}}$} & \multicolumn{2}{|c|}{ No of samples } \\
\hline & ${ }^{\circ} \mathrm{N}$ & ${ }^{\circ} \mathrm{E}$ & & & & Sediment & Water \\
\hline Dyksterhusen & 53.2935 & 7.2291 & $\begin{array}{l}\text { Transitional waters. } \\
\text { fully mixed. mesotidal }\end{array}$ & Incoming tide & Good & $22^{\mathrm{b}, \mathrm{e}, \mathrm{f}}$ & $22^{\mathrm{b}, \mathrm{e}, \mathrm{f}}$ \\
\hline Borkum & 53.58765 & 6.65618 & Euhaline exposed. fully mixed & Incoming tide & Excellent & $24^{\mathrm{f}}$ & $24^{\mathrm{f}}$ \\
\hline Norddeich & 53.6176 & 7.1493 & Polyhaline. exposed. fully mixed & Outgoing tide & Excellent & $24^{\mathrm{b}}$ & $24^{\mathrm{b}}$ \\
\hline Norderney & 53.7017 & 7.1493 & Polyhaline. Wadden Sea type & Outgoing tide & Excellent & 25 & 25 \\
\hline Duhnen & 53.8857 & 8.6352 & Polyhaline. Wadden Sea type & Incoming tide & Excellent & 25 & $24^{\mathrm{c}}$ \\
\hline Dorum & 53.7416 & 8.5139 & Polyhaline. Wadden Sea type & Incoming tide & Excellent & $21^{\mathrm{b}, \mathrm{c}, \mathrm{d}, \mathrm{f}}$ & $21^{\mathrm{b}, \mathrm{c}, \mathrm{d}, \mathrm{f}}$ \\
\hline Wremen & 53.6460 & 8.4916 & $\begin{array}{l}\text { Transitional waters. } \\
\text { fully mixed. mesotidal }\end{array}$ & Incoming tide & Excellent & $21^{b, c, d, f}$ & $22^{b, c, f}$ \\
\hline Burhave & 53.58361 & 8.37606 & $\begin{array}{l}\text { Transitional waters. } \\
\text { fully mixed. mesotidal }\end{array}$ & Incoming tide & Excellent & 25 & 25 \\
\hline Bremerhaven & 53.3216 & 8.3435 & $\begin{array}{l}\text { Transitional waters. } \\
\text { fully mixed. mesotidal }\end{array}$ & Incoming tide & No designated beach & 25 & 25 \\
\hline Dedesdorf & 53.44387 & 8.49837 & $\begin{array}{l}\text { Transitional waters. } \\
\text { fully mixed. mesotidal }\end{array}$ & Incoming tide & No designated beach & 25 & 25 \\
\hline
\end{tabular}

${ }^{a}$ According to the requirements of the European Bathing Water Directive; results from 2011

${ }^{\mathrm{b}}$ December 2009 sample missing

${ }^{\mathrm{c}}$ January 2010 sample missing

${ }^{\mathrm{d}}$ February 2010 sample missing

${ }^{\text {e }}$ March 2010 sample missing

${ }^{\mathrm{f}}$ December 2011 sample missing

(Merck). The filters were transferred onto CHROMagar ${ }^{\mathrm{TM}}$ Vibrio (CHROMagar, France) and incubated for 18-24 h at $36{ }^{\circ} \mathrm{C}$. Alternatively, sample volumes of $0.1 \mathrm{~mL}$ (only in summer) to $1 \mathrm{~mL}(2 \times 0.5 \mathrm{~mL}$ due to the maximum capacity of the plates) were plated onto CHROMagar ${ }^{\mathrm{TM}}$ Vibrio directly with a drigalski spatula, and incubated correspondingly.
Two approaches were also used for the detection of Vibrio spp. in sediments. Using the most probable number (MPN) technique, the sediments were diluted fourfold in buffered peptone water (Merck, supplemented with additional $\mathrm{NaCl}$ giving a final concentration of $1.5 \% \mathrm{NaCl}$ ). The dilution series were incubated for $18-24 \mathrm{~h}$ at $36{ }^{\circ} \mathrm{C}$,
Fig. 1 Overview over the sampling area. Mean salinities for the period January 2009 to December 2010 at the sampling sites are depicted in grey shading (Salinity chart courtesy of Dr. Uwe Brockmann and Monika Schütt, University of Hamburg)




followed by sub-cultivation on CHROMagar ${ }^{\mathrm{TM}}$ Vibrio and incubation at $36^{\circ} \mathrm{C}$ for additional $18-24 \mathrm{~h}$. All MPN series were done in triplicate.

Alternatively, $60 \mathrm{~g}$ of the sediment sample was mixed with $60 \mathrm{~mL}$ of distilled water and $60 \mathrm{~mL}$ of SMD (synthetic sea salt solution, Dr. Brinkmann Floramed $\mathrm{GmbH}$ ) for $30 \mathrm{~min}$ on a magnetic stirrer in order to extract the bacteria from the sediments. The sediment was left to settle, followed by removal of the supernatant. Volumes of 0.1 to $10 \mathrm{~mL}$ of the supernatant were membrane filtered and filters transferred onto CHROMagar ${ }^{\mathrm{TM}}$ Vibrio. Filtration of volumes $<10 \mathrm{~mL}$ was augmented by the addition of a sterile $\mathrm{NaCl}$ solution. In addition, $1 \mathrm{~mL}$ of supernatant was directly plated onto CHROMagar ${ }^{\mathrm{TM}}$ Vibrio. All plates were incubated for $18-24 \mathrm{~h}$ at $36^{\circ} \mathrm{C}$.

Presumptive Vibrio spp. colonies were tested for oxidase activity using Bactident ${ }^{\circledR}$ Oxidase test strips (Merck). Randomly, colonies were microscopically examined for motility and shape. For further differentiation of presumptive $V$. vulnificus and $V$. cholerae, pure cultures of green blue to turquoise blue colonies were grown on thiosulphate citrate bile sucrose agar (TCBS, Merck; green, V. vulnificus; yellow, V. cholerae). In the case of colonies with multiple shapes and colours (e.g. lighter blue to darker blue), several colonies of each variant were sub-cultivated. In the case of morphological uniformity, single representatives were picked. All colonies destined for further species identification were sub-cultivated on Columbia blood agar (Oxoid) prior to biochemical testing. All presumptive $V$. vulnificus and $V$. cholerae isolates, and randomly chosen representatives of presumptive $V$. parahaemolyticus and $V$. alginolyticus were subjected to the Analytical Profile Index (API) system API20E (BioMérieux, Marcy L'Etoile, France). Verified V. cholerae isolates were further examined for O1, O139, Inaba and Ogawa serotypes via agglutination testing (antiserum ZM05 (Murex), O139 "Bengal" antiserum 294487 (Denka Seiken), polyvalent antiserum 293831 (Denka Seiken), antisera No. 3133, 2890 and 3609 of the Robert Koch institute). Based on the species assignment, colony counts were converted to concentrations of colony-forming units (cfu)/100 mL water and cfu/100 g sediment, respectively. According to common microbiological surveillance practice, the highest concentration of Vibrio spp. in a sample yielded by any of the approaches was used for further data analyses.

\section{PCR Detection of Species-Specific} and Virulence-Associated Gene Targets

In order to check the reliability of the species assignment via culturing and biochemical testing, a number of Vibrio strains that were isolated during the study and became part of our strain collection were tested for species-specific and additionally for virulence-associated genes via PCR. $V$. vulnificus as the main agent of Vibrio-related wound infections in Germany is primarily represented in this collection. As described previously [42], genomic DNA of 35 V. parahaemolyticus, 106 $V$. vulnificus and $22 \mathrm{~V}$. cholerae strains was prepared using a lysozyme/SDS lysis followed by a phenol/chloroform extraction and an isopropanol precipitation. All PCR reactions were conducted in triplicates with $10 \mathrm{ng}$ of template DNA for each of the strains. The universal forward primer UtoxF was used in combination with species-specific primers for VvtoxR, VptoxR and $V$ ctoxR, respectively [43, 44]. For $V$. vulnificus strains, $10 \mathrm{ng}$ of template DNA was used, and the PCR mixture contained $2.5 \mu \mathrm{L}$ Taq buffer $(10 \times), 5 \mu \mathrm{L}$ Taq Master PCR Enhancer (5×), 10 pmol of each primer, $10 \mathrm{mM}$ dNTPs and 1 . 5 U Taq DNA polymerase (5 Prime). UtoxR/VvtoxR fragments were amplified under the following PCR conditions: 4 min at $94{ }^{\circ} \mathrm{C}, 30$ cycles of $94^{\circ}$ for $30 \mathrm{~s}, 61^{\circ} \mathrm{C}$ for $30 \mathrm{~s}, 68^{\circ} \mathrm{C}$ for $30 \mathrm{~s}$ with a final $68^{\circ} \mathrm{C}$ extension of $7 \mathrm{~min}$. All $V$. parahaemolyticus strains were additionally screened for the hemolysin genes $t d h$ and $t r h[43,45]$. Parameters used for all $V$. parahaemolyticus PCRs (VptoxR/tdh/trh) were the same as for the identification of tox $R$ genes in $V$. vulnificus with two exceptions: annealing was performed at $62{ }^{\circ} \mathrm{C}$ for $1 \mathrm{~min}$ and elongation at $68^{\circ} \mathrm{C}$ for $1 \mathrm{~min}$. For $V$. cholerae, a multiplexPCR was performed with the primer sets UtoxF/VctoxR, $O 139 F / O 139 R, c t x A 1 / c t x A 2$ and $O 1 F / O 1 R$ [43, 46, 47]. Half a micromole of each O1 Primer and $0.125 \mu \mathrm{mol}$ of every other primer were used. After a denaturation of 4 min at $94{ }^{\circ} \mathrm{C}$, 30 cycles were employed $\left(94{ }^{\circ} \mathrm{C}-30 \mathrm{~s} ; 59^{\circ} \mathrm{C}-30 \mathrm{~s}, 68^{\circ} \mathrm{C}-\right.$ $30 \mathrm{~s}$ ) with an extension of $5 \mathrm{~min}$ at $68^{\circ} \mathrm{C}$. Resulting PCR products were analysed by agarose gel electrophoresis $(2 \%$ agarose; $0.5 \times \mathrm{TBE}$ ). Gels were run at $80 \mathrm{~V}$ for $90 \mathrm{~min}$, stained with GelRed and visualized using the ChemiDoc XRS imaging System (Bio-Rad). The following reference strains were used as positive controls: V. vulnificus DSM-10143 (VvtoxR), V. parahaemolyticus RIMD 2210633 (VptoxR and trh), $V$. parahaemolyticus $\mathrm{VN}-0088(t d h)$, V. cholerae $\mathrm{VN}-0147$ (O1), V. cholerae VN-0150 (O139) and V. cholerae VN-0156 $(\operatorname{ctxA})$. Vibrio harveyi was used as negative control.

\section{Kanagawa Test}

The $35 \mathrm{~V}$. parahaemolyticus isolates and reference strain $V$. parahaemolyticus DSZM 11058 were tested for the Kanagawa phenomenon as described by Oberbeckmann et al. [42].

Environmental Parameters

Weather data were provided by the National Meteorological Service (DWD). The salinity of the water samples was determined according to Mohr [48] as defined in DIN 38405-1 [49] using an automatic titrator (Mettler Toledo DL55). Salinities were calculated according to Knudsen [50]. 
Sediments were characterized as follows: sediments were freeze-dried, homogenized and particles $>2 \mathrm{~mm}$ separated from the rest of the sediment by dry sieving. The $<2-\mathrm{mm}$ fraction was split on a rotor sampler and one to two parts of the sediment grinded using a planetary mill with zirconium vessels and beads. This sub-sample was subjected to TOC analysis according to DIN EN 12137 [51]. Two to three parts of the remaining sediment were used to determine grain sizes via ultrasonic sieving as described elsewhere [52]. For each season $(21 / 06-20 / 09=$ summer, $21 / 09-20 / 12=$ fall, $21 / 12$ $20 / 03=$ winter, $21 / 03-20 / 06=$ spring) a representative sediment sample was analysed for grain size distribution with the KVS software (author: Dr. Johann Buss, Braunschweig/Germany, version 4.01, 20/02/1997). The sediment classification was carried out according to Figge et al. [53]. In case of seasonal variations in the sediment classifications, additional sediment samples were analysed and averages used for data processing. The percentage of clay and silt was used for statistical analyses.

\section{Statistical Analyses}

The open-source program $R$ (R Development Core Team (2008). R: A language and environment for statistical computing. R Foundation for Statistical Computing, Vienna, Austria; version 2.15.1) was used for all statistical calculations. All bacterial parameters were $\log _{10}(x+1)$-transformed prior to the analyses. In cases were bacterial levels were below the detection limit of the available method, a value of zero was assigned prior to logarithmic conversion. Occasional values above detection limits were set to the detection limit value plus one in order to allow differentiation for rank tests. TOC values below detection limit were assigned half the value of the limit. Weather data were selected as follows: global solar irradiance as the sum of 3 days before sampling, sunshine duration as the sum of 1 week before sampling as well as cloud cover, rainfall, wind direction and wind speed as a weekly mean.

Variations in Vibrio abundance between seasons and sampling sites were tested for significance using the KruskalWallis test. Pairwise comparisons between samples were conducted using the kruskalmc function for Kruskal-Wallis post hoc tests on dependent variables as implemented in the $R$ package pgirmess.

Multiple correlations between Vibrio species and all environmental parameters were calculated by using Spearman's rank correlation coefficient, and significances were adjusted for multiple comparisons by the Bonferroni method $[p<0.000292(0.05 / 171)]$. Environmental parameters were tested for their impact on the occurrence and abundance of individual Vibrio species via stepwise multiple logistic regression analyses and stepwise multiple linear regression analyses, respectively. Vibrio spp. in water and sediment were regarded separately. Regressions were considered significant when the $p$ value was $<0.05$. Additionally, probabilities of the presence of individual Vibrio species as a function of water temperature were visualized using simple logistic regression models.

\section{Particle Transport Model}

A possible drift of $V$. vulnificus from the Ems estuary to the island of Borkum in summer 2010 was checked using a particle transport model, which is developed and applied for drift simulations at the German Federal Maritime and Hydrographic Agency (BSH). The 3D, baroclinic regional ocean circulation model BSHcmod [54] calculates the threedimensional current field as well as water level, temperature, salinity and ice cover in the North Sea and the Baltic Sea with an overall horizontal resolution of $5.5 \mathrm{~km}$ and $900 \mathrm{~m}$ resolution in the German Bight and the western Baltic Sea. The model includes tidal and meteorological forcing, as well as baroclinic effects due to temperature changes and varying river discharge.

Based on archived results from BSHcmod, the drift of particles is calculated by the particle transport model BSHdmod.L [55]. Both model components make use of meteorological forcing data provided by the weather prediction models of the DWD.

\section{Results}

Seasonal and Spatial Distribution of Vibrio spp.

PCR testing for species-specific tox $R$ genes verified that 35 V. parahaemolyticus, $106 \mathrm{~V}$. vulnificus and 21 out of 22 tested $V$. cholerae isolates belonged to the supposed species assigned in API testing, thus proving the reliability of our culturing approach. All four potentially pathogenic Vibrio species were detected during the study period. V. alginolyticus was by far the most frequently occurring species and could be detected in $79 \%$ of water samples and $94 \%$ of sediment samples, respectively. The second most frequent species was $V$. parahaemolyticus with 44 and $67 \%$ of positively tested water and sediment samples, respectively. Five percent of water and sediment samples contained $V$. vulnificus, while $V$. cholerae were detected in $2 \%$ of water samples and $4 \%$ of sediment samples, respectively, with all isolates belonging to the non-O1/O139 type. Vibrio spp. were not only present more often in sediments than in water but benthic $V$. alginolyticus, V. parahaemolyticus, and $V$. vulnificus were also one to three times more abundant. Mean $V$. alginolyticus concentrations ranged from $1.5 \times 10^{3}$ to $2.9 \times 10^{5} \mathrm{cfu} / 100 \mathrm{~g}$ in sediments and from $6 \times 10^{1}$ to $8.4 \times 10^{4} \mathrm{cfu} / 100 \mathrm{~mL}$ in water, mean V. parahaemolyticus concentrations ranged from $7.6 \times 10^{2}$ to $1.6 \times 10^{5} \mathrm{cfu} / 100 \mathrm{~g}$ in sediments and from $3.6 \times 10^{1}$ to $6.3 \times$ $10^{3} \mathrm{cfu} / 100 \mathrm{~mL}$ in water, and $V$. vulnificus concentrations ranged from 0 to $4.8 \times 10^{3} \mathrm{cfu} / 100 \mathrm{~g}$ in sediments and from 
0 to $4.6 \times 10^{1} \mathrm{cfu} / 100 \mathrm{~mL}$ in water samples (Table S3). $V$. cholerae was detected only in very low numbers $(0-$ $5 \mathrm{cfu} / 100 \mathrm{~mL} ; 0-7 \mathrm{cfu} / 100 \mathrm{~g}$ ) both in sediment and water.

A strong correspondence between water temperature and the presence and abundance of $V$. alginolyticus, $V$. parahaemolyticus and $V$. vulnificus was observed in this study. Water temperature values ranged from $0{ }^{\circ} \mathrm{C}$ in winter to $26.5^{\circ} \mathrm{C}$ in summer (Table S1), with the highest water temperatures occurring primarily in July or August. Correspondingly, the number of samples positively tested for $V$. alginolyticus, $V$. parahaemolyticus and $V$. vulnificus was highest in these months. Furthermore, the abundance of these three species significantly increased with increasing temperature, while $V$. cholerae did not show a significant seasonal pattern (Fig. 2, for results of nonparametric post hoc tests see Table S2). Figure 2 shows clearly that, despite the general trend towards elevated presence and abundance at high water temperatures, $V$. alginolyticus, $V$. parahaemolyticus and $V$. vulnificus had a distinct species-specific response towards temperature changes. While $V$. alginolyticus and $V$. parahaemolyticus were present the whole year, $V$. vulnificus was only detected at temperatures between 14 and $26.5^{\circ} \mathrm{C}$. Presence of $V$. vulnificus at water temperatures $<20{ }^{\circ} \mathrm{C}$ appears to be uncommon compared to what other studies have shown. However, this was only true for fall samples (Fig. 3); in most samples, a threshold of $20^{\circ} \mathrm{C}$ had to be reached before culturable $V$. vulnificus cells could be detected. Once reached, $V$. vulnificus appeared suddenly, and could be found for several months even at decreasing temperatures (Figs. 2 and 3).

$V$. alginolyticus and $V$. parahaemolyticus were both present even at temperatures around freezing point. $V$. alginolyticus, however, was overall less sensitive towards cold temperatures than $V$. parahaemolyticus, and was more or less frequently present at all sites throughout May until November (Fig. S1). Presence of $V$. parahaemolyticus, in contrast, followed the seasonal temperature changes with a lag of 1 to 2 months, such that the number of positively tested samples was highest in August (2010) and September (2011), respectively, while decreasing with decreasing water temperature. Interestingly, the impact of water temperature on both organisms was found to be more pronounced in water than in sediment samples, all the more for $V$. parahaemolyticus, indicating a protective effect of the sediments at low temperatures.

$V$. alginolyticus, $V$. parahaemolyticus and $V$. vulnificus did not only show species-specific responses to water temperature, but exhibited species-specific spatial distribution patterns as well. Although mean salinities in the study area ranged from 4.1 to $27.4 \mathrm{psu}, V$. alginolyticus and $V$. parahaemolyticus were ubiquitously distributed over the entire region. However, their abundance varied significantly between sites in both sediment and water for $V$. alginolyticus ( $K=37.4$ and $K=49.3$, respectively; $p<0.001$ ) as well as in sediments for $V$. parahaemolyticus $(K=31.2 ; p<0.001$; Fig. S2; for results of the nonparametric post hoc tests see Table S4). Highest mean $V$. alginolyticus and $V$. parahaemolyticus abundances occurred at mean salinities of approximately $15-17$ psu, while mean cell numbers were generally lower in brackish waters or at higher salinities. In contrast, $V$. vulnificus occurrence was, with one exception, restricted to sites within the Ems and Weser estuaries where the lowest mean salinities of 4.1 to 17.2 psu were measured, and its abundance did not vary significantly between these sites. Figure 4 shows the range of salinities (4.1-17.2 psu) and water temperatures $\left(14-26.5^{\circ} \mathrm{C}\right)$ at which $V$. vulnificus was present. In contrast to $V$. alginolyticus and $V$. parahaemolyticus, the sediments did not have an effect on the tolerance of $V$. vulnificus towards cold water temperatures nor did they change the acceptable salinity range. The findings presume, however, that high temperatures could broaden the salinity tolerance of the organism because positive $V$. vulnificus detections at high temperatures were often related to high salinities, while $V$. vulnificus presence at lower temperatures was connected to low salinities. However, enhanced salinity in the Weser estuary due to reduced precipitation and riverine freshwater input in summer usually coincides with particularly high water temperatures due to the high thermal load of the river, which could cause this trend. Figure 4 shows that despite its preference for brackish waters, $V$. vulnificus may occasionally occur at salinities that are far beyond the salinity range that is usually tolerated by this organism: $V$. vulnificus occurred in Borkum sediment in September 2010, although Borkum is strongly influenced by the open North Sea and has the highest mean salinity of all sites (Table S1). Since $V$. vulnificus occurred at the Dyksterhusen site in July and August 2010 prior to its detection on Borkum 1 month later, we hypothesized that $V$. vulnificus may have drifted towards Borkum with freshwater currents deriving from the Ems estuary. This was tested with a computational simulation. The particle transport model, which considered current and wind regimes in this area during late summer 2010, showed that $V$. vulnificus in Borkum may have had its origin in the Ems estuary (Fig. 5), suggesting that it can be transported over longer distances.

Impact of Environmental Variables on Bacterial Parameters

In a first step, interactions between environmental variables and Vibrio spp. were analysed using the Spearman's rank correlation test. Figure 6 (see also Table S5) shows a summary of all statistically significant correlations. $V$. cholerae was the only species that was not significantly correlated to any of the parameters and is thus not represented in the figure. The scheme clearly demonstrates that Vibrio abundance in sediment and water was strongly positively correlated, suggesting an intense link between the Vibrio communities 
Water

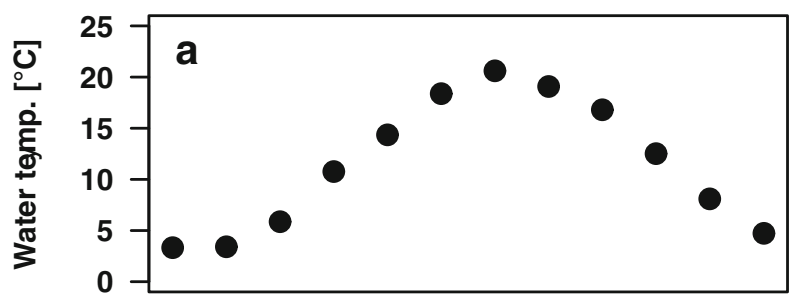

ำ

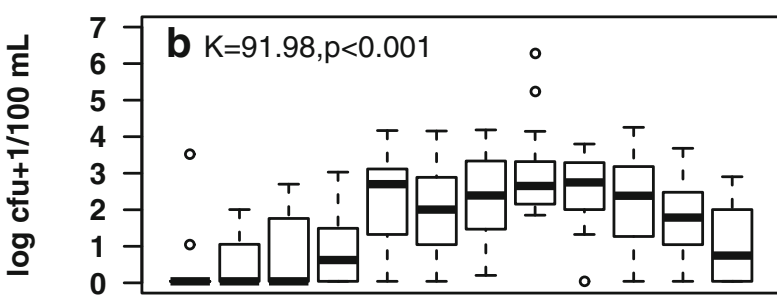


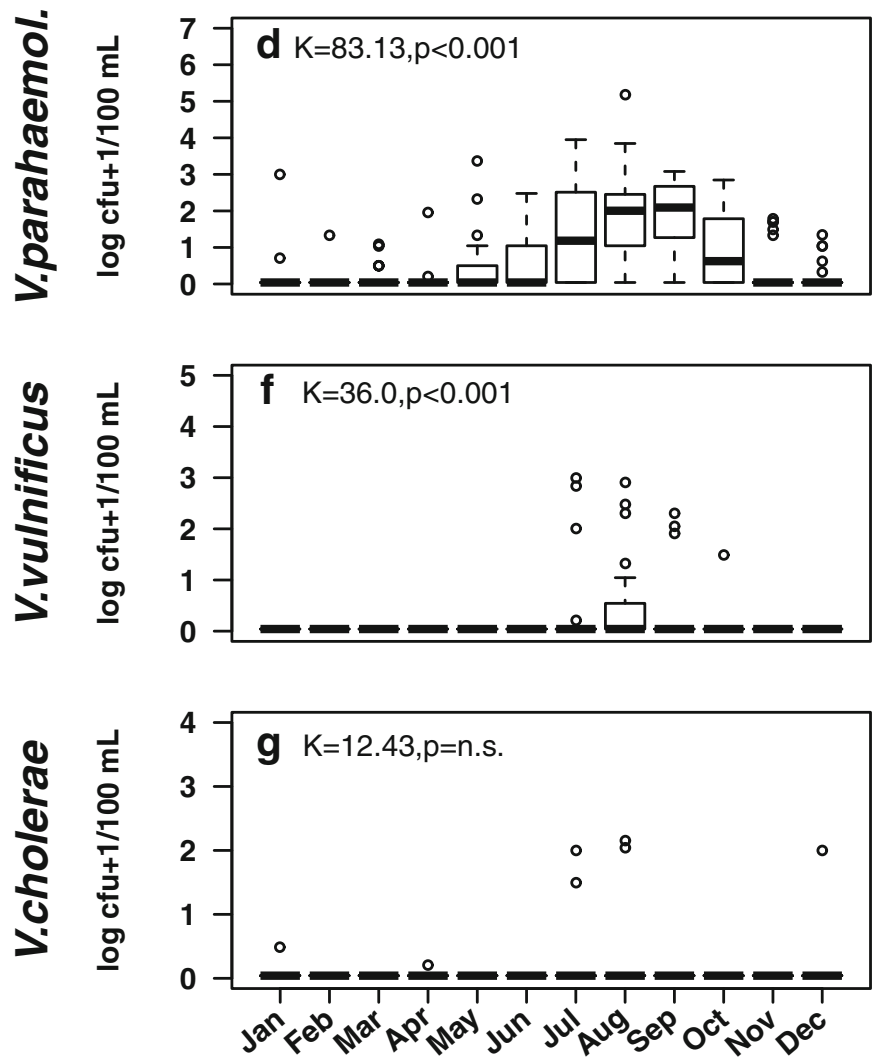

Fig. 2 Figure visualizing the seasonal variations in Vibrio abundances in water (left column) and sediment (right column). The upper two plots (a) show the mean water temperatures that were measured each month while sampling. Boxplots represent the seasonal variations in abundances of $V$. alginolyticus (b, c), V. parahaemolyticus $(\mathbf{d}, \mathbf{e}), V$. vulnificus $(\mathbf{f}, \mathbf{g})$, and $V$. cholerae $(\mathbf{h}, \mathbf{i})$, respectively. Thick bars in the boxes represent the sample

in both compartments. Water temperature was the most important factor that was significantly and positively correlated to $V$. vulnificus, $V$. parahaemolyticus and $V$. alginolyticus abundance in sediment and water, thus mirroring the observed seasonal
Sediment
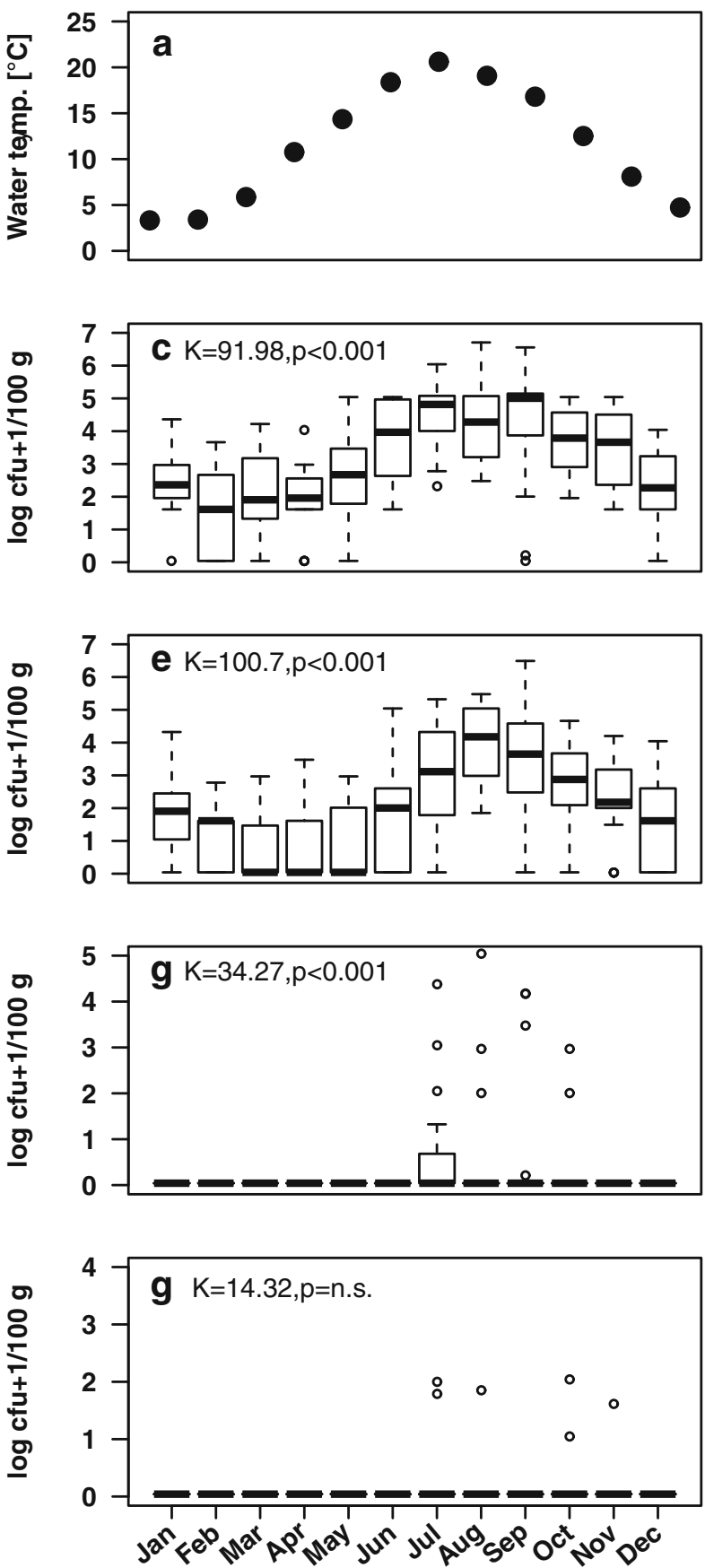

median, boxes themselves show the upper and lower quartiles, whiskers show the range and circles represent outliers. Outliers are defined as data points that fall below the first quartile or exceed the third quartile by 1.5 times the interquartile range. Kruskal-Wallis test statistics $(K)$ and significance levels $(p)$ for comparison of abundances between seasons are given in the top left corner of each sub-plot

distribution patterns of these three species. The weather data exhibited various interdependences. As expected, global solar irradiance and sunshine duration were strongly correlated with each other and showed significant negative correlations with 
Fig. 3 Seasonal plot showing the number of $V$. vulnificuspositive samples per month in relation to water temperature. Bars represent the sum of positively tested samples (water and sediment combined); for line and scatters, the mean water temperature of all sampling sites was taken on a monthly basis. Arrows mark the months in which a temperature threshold of $20{ }^{\circ} \mathrm{C}$ was exceeded

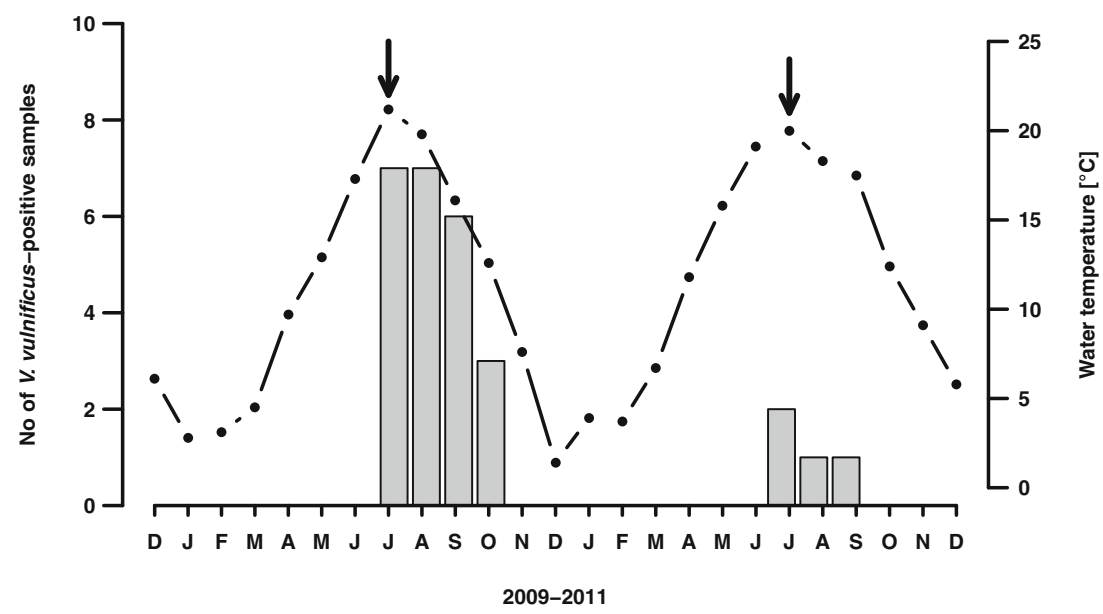

cloud cover, rainfall and wind speed, while being strongly positively correlated with water temperature. High wind speed in the North Sea is usually related to westerlies which often bring high amounts of rain to the region, a relationship that is reflected in the significant positive correlations between wind speed, wind direction and rainfall in Fig. 6. The positive relationship between water temperature and westerlies in combination with the negative relationship between water temperature and wind speed appears to be contradictory; however, westerlies predominate during the warmer seasons, while easterly winds occur mainly at winter time. The described relationships reflect the strong seasonal dynamics typical for the study area, where sunny weather and warm temperatures prevail in summer, while rainy and cloudy weather predominate in winter. Although individual positive correlations existed between high $V$. alginolyticus and $V$. parahaemolyticus abundance, and high global solar irradiance and long sunshine duration, the strongest effect of sunshine on Vibrio spp. was mainly indirect due to the effect of sunshine on water temperature. TOC contents were higher in fine sediments compared to coarse sediments, as reflected in the strong correlation between TOC and the clay and silt content of the sediments. Figure 6 shows that the abundance of benthic $V$. alginolyticus and $V$. parahaemolyticus was positively linked to these nutrientricher sediments. Fine-grained sediments predominated in the estuaries, while the coastal sites were mainly characterized by a sandy sediment type, which was reflected by the significant negative correlation between salinity and the clay and silt content of the sediments. Salinity itself was strongly dependent on the position of the sites and affected by dry weather periods as reflected in its positive link with global solar irradiance. Vibrio spp. and salinity were not significantly correlated.

In order to further investigate the impact of environmental parameters on the occurrence and abundance of Vibrio spp., stepwise multiple logistic and linear regression models were developed for each Vibrio species (except $V$. cholerae) in water and sediment individually. Those environmental parameters that exhibited a strong direct or indirect interdependence with water temperature (global solar irradiation, sunshine duration, cloud cover and wind speed) and salinity (space) in the correlation analysis were removed from further statistical steps. TOC was strongly connected to the clay and silt content of the sediments; thus, the latter was additionally excluded. Water temperature, salinity, TOC, wind direction and rainfall were kept as independent variables in the models.

The multiple stepwise logistic regression analyses showed that high water temperature was the crucial factor for the occurrence of $V$. alginolyticus, $V$. parahaemolyticus and $V$. vulnificus in water and sediment $(p<0.001$, except $V$. alginolyticus in sediment with $p<0.01$; Table 2), thus underlining the strong seasonality of Vibrio spp. occurrence observed in this study. Additionally, high salinity had a negative influence on the presence of $V$. parahaemolyticus in water and sediment $(p<0.01)$, and a positive effect on the presence of $V$. alginolyticus in sediment alone $(p<0.05)$, which indicates certain species-specific preferences towards salinity. Furthermore, the presence of benthic $V$. vulnificus and $V$. alginolyticus was negatively affected by westerlies $(p<0.01)$.

The results of the predictive models greatly reflected these patterns. High water temperature was not only related to the mere presence of $V$. alginolyticus, $V$. parahaemolyticus and $V$. vulnificus but had a strong positive effect on the abundance of all three species as well, and was the dominant factor in all models $\left(R^{2}=0.03\right.$ to 0.13 ; Table 3$)$. High salinity was an additional significant factor related to low abundance of $V$. vulnificus in water and sediment $\left(R^{2}=0.01\right)$, in contrast to high concentrations of $V$. alginolyticus in sediment $\left(R^{2}=0.03\right)$. Benthic $V$. alginolyticus and $V$. parahaemolyticus concentrations were significantly and positively affected by the nutrient contents of the sediments as represented by TOC $\left(R^{2}=0.42\right.$ and 0.45 , respectively), as well as with rainfall $\left(R^{2}=0.01\right)$, which is likely linked to freshwater-related nutrient inputs in the area. Rainfall also positively affected $V$. alginolyticus abundance in the water $\left(R^{2}=0.01\right)$. Furthermore, westerlies 



Fig. 4 Bubble plots showing the range of salinities and water temperatures at which $V$. vulnificus was detected in water (a) and sediment (b) in the study area. Bubble sizes depict size classes of $V$. vulnificus concentrations as described in the legends. A posteriori shaded areas visualize the water temperature and salinity ranges that favour $V$. vulnificus occurrence (Borkum presented as outlier)

had a strong negative impact on Vibrio spp. concentrations in the sediments $\left(R^{2}=0.02\right.$ to 0.07$)$ and on the abundance of $V$. vulnificus in water $\left(R^{2}=0.02\right)$, presumably due to the combined effect of pressing higher salinity water from the open North Sea into the study area, while reducing the share of nutrient-rich riverine waters.

Water temperature was the most important explanatory variable in all Vibrio models; however, the seasonal distribution of the individual Vibrio species suggested certain species-specific responses to changes in water temperature (Fig. 2). In order to take a closer look at these individual relationships, a simple logistic regression model was created for each of the three Vibrio species in order to predict the probability of their detection as a function of water temperature. Figure 7 is based on presence/absence data from both the sediment and water, and clearly demonstrates that the responses of $V$. alginolyticus, $V$. parahaemolyticus and $V$. vulnificus to temperature increases were in fact individually different. The simple logistic regression model of $V$. alginolyticus strongly reflected the good adaptation of this organism to cold temperatures, with a $85 \%$ probability of detecting $V$. alginolyticus even at water temperatures around freezing point. Below $10{ }^{\circ} \mathrm{C}$, even minor increases in water temperature strongly affected $V$. alginolyticus presence in the area, and at $10^{\circ} \mathrm{C}$, the probability of detecting $V$. alginolyticus was already $95 \%$, which reflects the (almost) year-round presence of $V$. alginolyticus in the study area. Above $10{ }^{\circ} \mathrm{C}$, the effect of water temperature on $V$. alginolyticus presence decreases substantially. At a temperature of $25{ }^{\circ} \mathrm{C}$ however, $100 \%$ of samples will probably contain culturable $V$. alginolyticus. In comparison, V. parahaemolyticus is quite well adapted to cold temperatures, however not as good as $V$. alginolyticus. At $0{ }^{\circ} \mathrm{C}$, the probability of detecting this species in the study area is $60 \%$, thus $25 \%$ lower than the probability of detecting $V$. alginolyticus. Below $15{ }^{\circ} \mathrm{C}$, an increment of $1{ }^{\circ} \mathrm{C}$ enhances the probability of $V$. parahaemolyticus detection by $\sim 1.5 \%$; above $15{ }^{\circ} \mathrm{C}$ this trend slows down slightly. At a temperature of $25{ }^{\circ} \mathrm{C}$, the probability of $\mathrm{V}$. parahaemolyticus presence in the study area is more than $90 \%$, indicating that many sites, particularly those in the Weser estuary where highest summer temperatures occur, will harbour $V$. parahaemolyticus during summer time.

In contrast, $V$. vulnificus presence is strongly dependent on warm temperatures as demonstrated in Fig. 7c, and the species is not likely to be present at water temperatures below $15^{\circ} \mathrm{C}$. Above $15^{\circ} \mathrm{C}$, the probability of $V$. vulnificus presence rapidly increases. In a temperature range of $15-20^{\circ} \mathrm{C}$, an increment in $1{ }^{\circ} \mathrm{C}$ of water temperature increases the probability of $V$. vulnificus presence by $\sim 4 \%$. At water temperatures above $20^{\circ} \mathrm{C}$, every $1{ }^{\circ} \mathrm{C}$ increment even leads to a tenfold increase in the probability of $V$. vulnificus presence, indicating that water temperatures $>20^{\circ} \mathrm{C}$ strongly promote this species with substantial effects of even minor temperature changes.

\section{Pathogenic Potential of Vibrio Isolates}

$V$. parahaemolyticus and $V$. cholerae strains were further tested for presence of virulence-associated gene targets. None of the tested $V$. cholerae isolates contained the $O 1$, $O 139$ and $c t x A$ genes, corresponding to the results of the agglutination tests, thus indicating that all strains were nonvirulent representatives. Two $V$. parahaemolyticus isolates 
Fig. 5 Graphic showing a potential $V$. vulnificus drift from the Ems estuary (positive proof in July and August 2010) to Borkum (positive proof in September 2010), based on modeling of 1,000 hypothetical particles. Each symbol represents one particle and stands for a hypothetical $V$. vulnificus cell. The star marks the starting position of all particles at the beginning of the model calculations, which was set to the date of $V$. vulnficus detection on Borkum (September 08, 2012). Calculations were run backwards until the date of $V$. vulnificus detection at Dyksterhusen (August 18, 2012), and the most probable position of particles during this time is shown

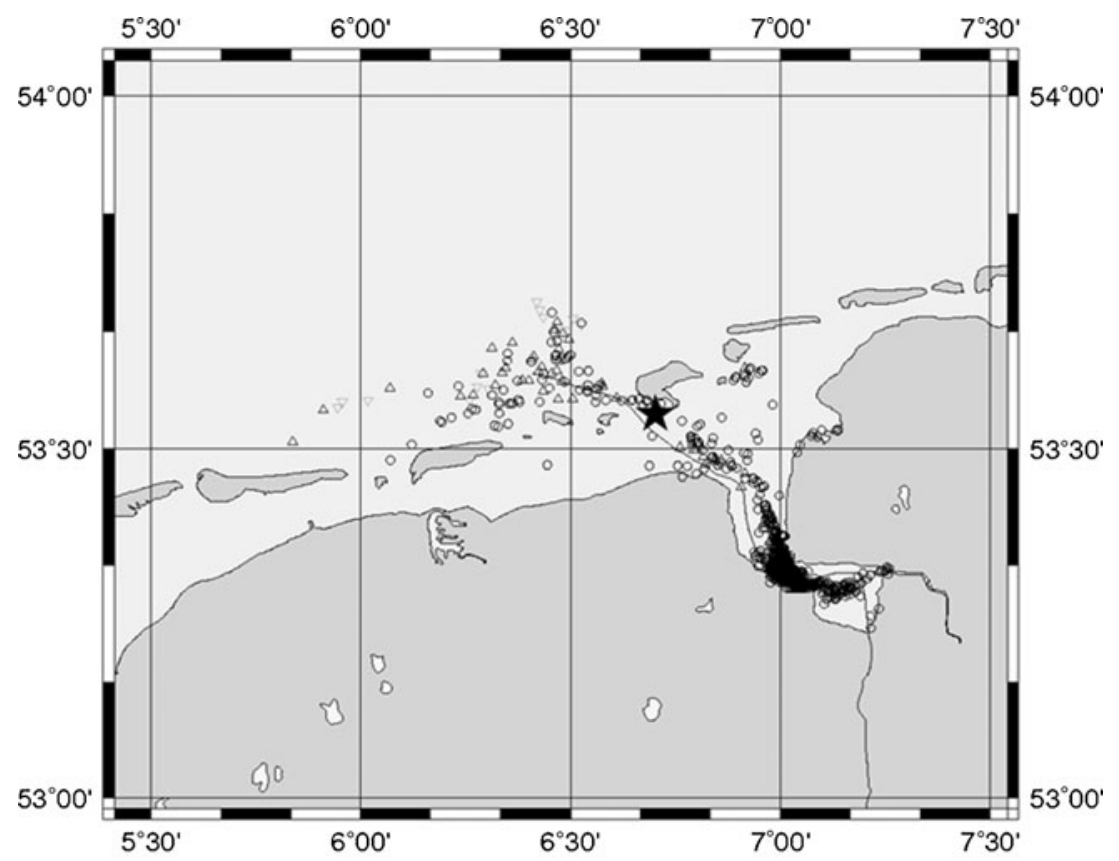

Particle positions 18.08 .2010 19:00 MEZ proved to have the trh gene; however, none had the $t d h$ gene that is supposed to be associated with haemolytic capability. In contradiction, two additional isolates that had neither the $t r h$ nor the $t d h$ gene showed haemolytic abilities in the Kanagawa test, suggesting the presence of additional haemolysis genes.

\section{Discussion}

The results of this study showed that $V$. alginolyticus, $V$. parahaemolyticus, $V$. vulnificus and $V$. cholerae occurred in water and sediment of recreational beaches in the central Wadden Sea and within the estuaries of the rivers Ems and Weser. The ecology of these bacteria was found to be very complex in this particularly dynamic ecosystem and characterized by distinct species-specific responses to environmental determinants, such as water temperature and salinity. $V$. alginolyticus was by far the most prevalent species in water and sediment, followed by $V$. parahaemolyticus, $V$. vulnificus and $V$. cholerae non-O1/non-O139. Earlier environmental studies in other parts of the North Sea region revealed comparable Vibrio community compositions [32, 35-37, 39, 56-58], suggesting that this distribution pattern could be a common feature of Vibrio communities along the North Sea coast.
V. cholerae non-O1/non-O139 occurred only sporadically and exhibited neither apparent seasonal nor spatial distribution patterns in this study. Furthermore, we could not identify any significant environmental drivers of $V$. cholerae occurrence. Since salinities were generally in a range where $V$. cholerae may occur [59], viability of this species must be controlled by some other determinants.

In contrast, $V$. alginolyticus, $V$. parahaemolyticus and $V$. vulnificus strongly responded to increases in water temperature, and followed distinct seasonal cycles in terms of isolation frequency and abundance, corresponding to earlier observations on Vibrio ecology [19, 60, 61]. Water temperature ranged between 0 and $26.5^{\circ} \mathrm{C}$ throughout the study, and was shown to be the crucial factor governing the occurrence and abundance of these three species in the study area, both in correlation analyses and regression models. The frequency of occurrence of $V$. alginolyticus, $V$. parahaemolyticus and $V$. vulnificus increased with increasing temperature, and the abundance of all three species was significantly higher in summer than in winter. Nevertheless, simple logistic regression models revealed a distinct species-specific response of $V$. alginolyticus, $V$. parahaemolyticus and $V$. vulnificus to water temperature. $V$. alginolyticus and $V$. parahaemolyticus persisted perennially in the study area; however, $V$. alginolyticus was found to be much better adapted to cold water temperatures than $V$. parahaemolyticus with a 


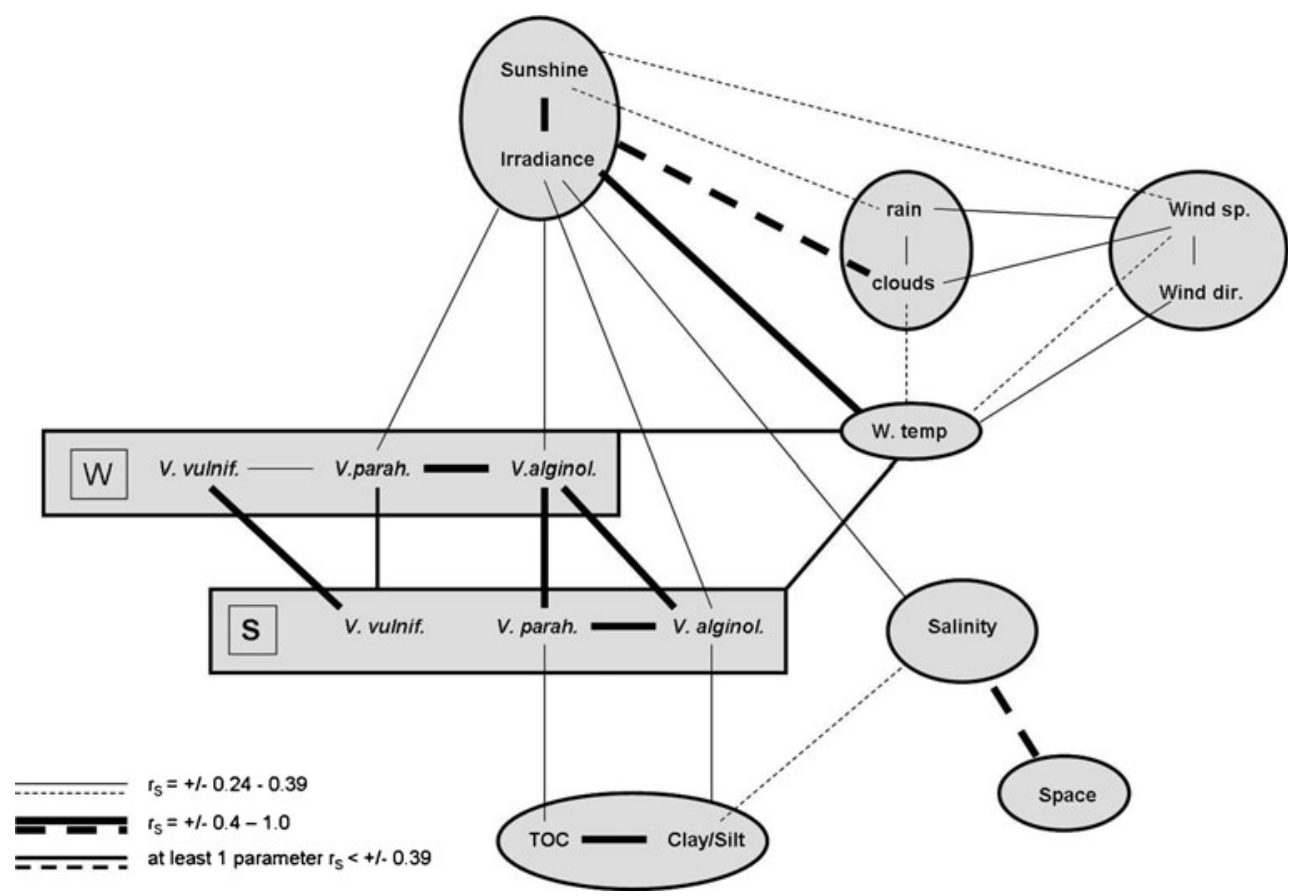

Fig. 6 Spearman's rank correlations between Vibrio species in sediment $(S)$ and water $(W)$, and the environmental variables. Data of the complete study are covered, and variables were partly grouped for better overview. Only significant correlations at the Bonferronicorrected level $p \leq 0.000292(0.05 / 171)$ are depicted. Thin and thick connecting lines represent significant correlations with coefficients of 0.24-0.39 and 0.4-1.0, respectively. Medium-sized lines represent connections where the correlation of at least two variables within

probability of the presence of the two species at freezing temperatures of 85 and $60 \%$, respectively. Increases in water temperature were accompanied by an increase in the probability of the presence of $V$. alginolyticus and $V$. parahaemolyticus in the study area. However, while the effect of temperature on $V$. alginolyticus presence diminishes substantially at temperatures $>10{ }^{\circ} \mathrm{C}$ (presumably because of other environmental factors becoming restrictive), V. parahaemolyticus profits considerably from further temperature increases. While the highest probability of the presence of $V$. alginolyticus corresponds to the highest water temperatures, maximum $V$. parahaemolyticus occurrence was shown to appear with a time lag of approximately 1 to 2 months, suggesting that interactions with other organisms could play an important role in $V$. parahaemolyticus ecology in the study area.

In contrast, presence of culturable $V$. vulnificus was found to be strongly dependent on water temperatures $>14{ }^{\circ} \mathrm{C}$. This species could be exclusively isolated at water temperatures of 14 to $26.5{ }^{\circ} \mathrm{C}$, supporting earlier studies that reported isolation of $V$. vulnificus only at water temperatures between 15 and $32{ }^{\circ} \mathrm{C}$ [4]. Interestingly, the isolation of $V$. vulnificus at water temperatures $<20^{\circ} \mathrm{C}$ succeeded only in autumn samples, while comparable spring samples remained negative. Our results clearly show that a threshold connected groups yielded a coefficient $<0.39$, but where the rest was more strongly connected. Lines connecting to a whole group of variables show that all variables within this group were correlated with the respective parameter. Individual correlations are represented by lines directly connected to single variables. Connecting lines are correlations with at least one of these two parameters. Continuous and dashed lines represent positive and negative coefficients, respectively

of $20^{\circ} \mathrm{C}$ has to be reached in order to establish $V$. vulnificus viability in the study area. Once present, the bacterium can remain culturable for several months even at lower temperatures without significant diminution in cell numbers, before vanishing abruptly. V. vulnificus responds particularly to strong to minor temperature increases when water temperature is overall high. Above $20{ }^{\circ} \mathrm{C}$, every $1{ }^{\circ} \mathrm{C}$ increment causes a tenfold increase in the probability of $V$. vulnificus presence.

Since $V$. vulnificus could not be detected at water temperatures $<14{ }^{\circ} \mathrm{C}$, the question remains as to from which sources the species is recruited at summer time. Previous studies suggested that $V$. vulnificus can withdraw into the sediments and remain in a viable but non-culturable state, when environmental conditions become unfavourable [62]; however, investigations on this topic were not within the scope of this study.

In addition to the species-specific responses of the three Vibrio species to water temperature, $V$. alginolyticus, $V$. parahaemolyticus and $V$. vulnificus showed diverging spatial distribution patterns that uncovered individual trends in terms of salinity preferences. A range of earlier studies in different regions described a strong relationship between salinity and he spatial distribution of Vibrio spp. [14-16]. Although salinity in 
Table 2 Results of the stepwise multiple logistic regression models

\begin{tabular}{|c|c|c|c|c|c|c|c|c|c|c|}
\hline & & & Estimate & Std. error & $z$ value & $\operatorname{Pr}(>|z|)$ & Significance & $\begin{array}{l}\text { Null } \\
\text { deviance }\end{array}$ & $\begin{array}{l}\text { Residual } \\
\text { deviance }\end{array}$ & $\mathrm{AIC}$ \\
\hline \multirow[t]{7}{*}{ Water } & \multirow[t]{2}{*}{ V. alginolyticus } & (Intercept) & -0.86 & 0.30 & -2.90 & 0.00 & $* *$ & \multirow[t]{2}{*}{282.32} & \multirow[t]{2}{*}{229.76} & \multirow[t]{2}{*}{233.76} \\
\hline & & Water temperature & 0.19 & 0.03 & 6.26 & 0.00 & $* * *$ & & & \\
\hline & \multirow[t]{3}{*}{ V. parahaemolyticus } & (Intercept) & -1.85 & 0.41 & -4.50 & 0.00 & $* * *$ & \multirow[t]{3}{*}{315.44} & \multirow[t]{3}{*}{262.45} & \multirow[t]{3}{*}{268.45} \\
\hline & & Water temperature & 0.17 & 0.03 & 6.29 & 0.00 & $* * *$ & & & \\
\hline & & Salinity & -0.05 & 0.02 & -2.70 & 0.01 & $* *$ & & & \\
\hline & \multirow[t]{2}{*}{ V. vulnificus } & (Intercept) & -8.06 & 1.64 & -4.92 & 0.00 & $* * *$ & \multirow[t]{2}{*}{101.09} & \multirow[t]{2}{*}{74.14} & \multirow[t]{2}{*}{78.14} \\
\hline & & Water temperature & 0.32 & 0.08 & 3.81 & 0.00 & $* * *$ & & & \\
\hline \multirow[t]{10}{*}{ Sediment } & \multirow[t]{4}{*}{ V. alginolyticus } & (Intercept) & 2.97 & 1.29 & 2.31 & 0.02 & $*$ & \multirow[t]{4}{*}{127.86} & \multirow[t]{4}{*}{110.38} & \multirow[t]{4}{*}{118.38} \\
\hline & & Water temperature & 0.14 & 0.05 & 2.73 & 0.01 & $* *$ & & & \\
\hline & & Salinity & 0.07 & 0.03 & 2.22 & 0.03 & $*$ & & & \\
\hline & & Wind direction & -0.14 & 0.07 & -2.10 & 0.01 & $*$ & & & \\
\hline & \multirow[t]{3}{*}{ V. parahaemolyticus } & (Intercept) & -1.85 & 0.41 & -4.50 & 0.00 & $* * *$ & \multirow[t]{3}{*}{315.44} & \multirow[t]{3}{*}{262.45} & \multirow[t]{3}{*}{268.45} \\
\hline & & Water temperature & 0.17 & 0.03 & 6.29 & 0.00 & $* * *$ & & & \\
\hline & & Salinity & -0.05 & 0.02 & -2.70 & 0.01 & $* *$ & & & \\
\hline & \multirow[t]{3}{*}{ V. vulnificus } & (Intercept) & -6.47 & 2.20 & -2.93 & 0.00 & $* *$ & \multirow[t]{3}{*}{101.09} & \multirow[t]{3}{*}{60.53} & \multirow[t]{3}{*}{66.53} \\
\hline & & Water temperature & 0.49 & 0.12 & 4.10 & 0.00 & $* * *$ & & & \\
\hline & & Wind direction & -0.25 & 0.11 & -2.32 & 0.02 & $*$ & & & \\
\hline
\end{tabular}

${ }^{*} p<0.05 ; * * p<0.01$; and $* * * p<0.001$, significant

the study was spatially and temporally variable covering a broad range from 0.6 to $33.5 \mathrm{psu}$, the overall effect of salinity on the distribution of Vibrio spp. in the study area was less important than the effect of water temperature. Particularly $V$. alginolyticus and $V$. parahaemolyticus tolerated the entire range of mean salinities between $\sim 4$ and 27 psu and were ubiquitously distributed at all sites in the study area. Nevertheless, the regression models revealed that the presence of $V$. alginolyticus and V. parahaemolyticus at individual time points was linked to species-specific salinity preferences. While high salinity values were shown to be significantly negatively correlated to occurrence of $V$. parahaemolyticus, they exhibited a significant positive influence on the occurrence and abundance of $V$. alginolyticus. In contrast, presence of $V$. vulnificus was mainly restricted to sites within the Ems and Weser estuaries with mean salinities of $\sim 4$ to $17 \mathrm{psu}$, and $V$. vulnificus abundance in the study area was significantly related to low salinity. These findings reveal a preference of $V$. vulnificus for brackish waters, supporting earlier descriptions as an estuarine bacterium [11]. The present study showed, however, that $V$. vulnificus can occasionally occur at sites with high mean salinities that are usually not expected to be within the range tolerated by this bacterium. V. vulnificus was detected in sediments at Borkum beach in September 2010, a site highly influenced by the open North Sea. Results of a particle transport model showed that wind and current regimes at that time could have caused a drift of $V$. vulnificus from the Ems estuary to Borkum, suggesting that certain environmental conditions can favour short-term presence of $V$. vulnificus outside the estuaries.

Wind direction was determined as a significant determinant of Vibrio spp. in the regression models. Particularly in

Table 3 Full predictive multiple linear regression models for $\log _{10}$ V. alginolyticus, $\log _{10}$ V. parahaemolyticus and $\log _{10}$ V. vulnificus in sediment and water, respectively

\begin{tabular}{|c|c|c|c|}
\hline Predictable variable $\left(\log _{10}\right)$ & Full multiple linear regression model & $R^{2}$ & $p$ \\
\hline V. alg.water & $=(0.10 \times$ water temp. $)+(0.01 \times$ rain $)+0.40$ & 0.24 & $<0.001$ \\
\hline V. alg. Sediment & $=(0.13 \times$ water temp.$)+(0.03 \times$ salinity $)-(0.06 \times$ wind direction $)+(0.42 \times \mathrm{TOC})+(0.01 \times$ rain $)+2.14$ & 0.30 & $<0.001$ \\
\hline V. parah.water & $=(0.07 \times$ water temp. $)-0.08$ & 0.19 & $<0.001$ \\
\hline V. parah. Sediment & $=(0.11 \times$ water temp. $)+(0.45 \times$ TOC $)-(0.07 \times$ wind direction $)+(0.01 \times$ rain $)+1.73$ & 0.19 & $<0.001$ \\
\hline V. vuln. Water & $=(0.03 \times$ water temp. $)-(0.02 \times$ wind direction $)-(0.01 \times$ salinity $)+0.35$ & 0.13 & $<0.001$ \\
\hline V. vuln. Sediment & $=(0.04 \times$ water temp. $)-(0.02 \times$ wind direction $)-(0.01 \times$ salinity $)+0.30$ & 0.12 & $<0.001$ \\
\hline
\end{tabular}

Significant explanatory variables determined following a stepwise forward selection procedure 

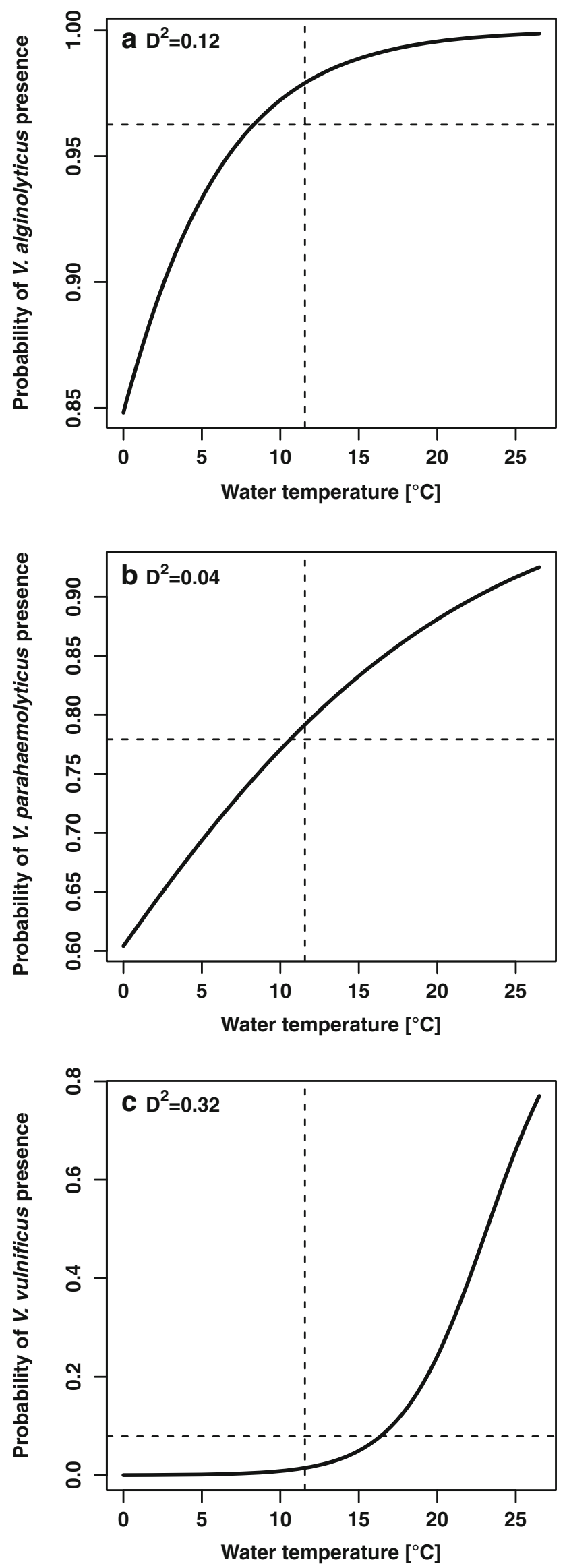

Fig. 7 Simple logistic regression models presenting the predicted probabilities for the presence of $V$. alginolyticus (a), V. parahaemolyticus (b) and $V$. vulnificus (c) in the study area as a function of water temperature. Combined data from sediment and water samples were considered for the analyses. The test statistic $D^{2}$ describes the overall model performance and is given in the upper left corner of each sub-plot

the sediments, wind direction significantly influenced the occurrence of $V$. vulnificus and $V$. alginolyticus, and the abundance of all three species, respectively. Low abundance of $V$. alginolyticus, $V$. parahaemolyticus and $V$. vulnificus was significantly connected to westerly, which usually presses high salinity water from the open North Sea into the study area, while reducing the share of nutrient-rich riverine waters. In contrast, rainfall had a minor positive effect on $V$. alginolyticus and $V$. parahaemolyticus abundance which can likely be linked to a higher share of nutrient-rich freshwater in the area.

Results of this study further show that sediments play a very important role for Vibrio ecology in this temperate environment. Culturable estimates of $V$. alginolyticus, $V$. parahaemolyticus and $V$. vulnificus were generally one to three orders of magnitude higher in sediments than in water and were $\sim 10^{5} \mathrm{cfu} / \mathrm{g}$ wet sediment in summer. Although previous studies in different regions showed that sediments can harbour high amounts of Vibrio spp. [12, 40, 63, 64], such a high difference in the number of viable cells between sediment and water seems to be extraordinary. The possibility of an active benthic lifestyle of Vibrio spp. has not been seriously discussed [12]. The sediments in general are mainly regarded as a retreat for Vibrio under unfavourable environmental conditions, for example, low temperatures. Our results indicate that sediments in fact may exhibit a protective effect on $V$. alginolyticus and particularly $V$. parahaemolyticus at winter time. However, with regard to the generally high numbers of $V$. alginolyticus, V. parahaemolyticus and $V$. vulnificus in sediments reported here, it seems likely that Vibrio spp. are active members of the benthic bacterial community. Vibrio spp. can use a large variety of different carbon sources $[65$, 66], and a significant positive relationship between TOC and the abundance of $V$. alginolyticus and $V$. parahaemolyticus in sediments observed in this study suggests that these species could potentially gain energy from benthic organic carbon mineralization.

In order to get a first idea of the pathogenic potential of Vibrio spp. occurring in the study area, a limited number of $V$. parahaemolyticus and V. cholerae strains that were isolated during the study were checked for the presence of virulence-related genes. Thirty-five $V$. parahaemolyticus strains were tested for the presence of $t d h$ and $t r h, 22 \mathrm{~V}$. cholerae strains for the presence of ctxA,O1 and O139, respectively. None of the $V$. cholerae strains was pathogenic, supporting the results of our agglutination tests. Only two $V$. parahaemolyticus isolates tested positive for presence of the 
trh gene, but not for $t d h$. Comparisons with other studies show that generally between 3 and $5 \%$ of environmental $V$. parahaemolyticus isolates bear either of the two virulence gene markers $[67,68]$. This suggests that the ratio observed here is realistic, although more strains need to be checked for more reliable evidence. Presence of the trh gene alone seems to be a common characteristic of $V$. parahaemolyticus communities in Northern European waters and has been shown for several studies in this region $[39,69,70]$. Up to now, only $t d h$-positive strains were associated with $V$. parahaemolyticus infections in Europe, however [68], and $t d h$ is the gene that has been mainly attributed to haemolysis [71]. Despite this, two strains that were identified as being $t d h$ and trh-negative exhibited haemolytic capacity in the Kanagawa test. This phenomenon has been described earlier [16], and additional genes than trh and $t d h$ have been suggested to be involved in V. parahaemolyticus haemolysis $[67,72]$. The small percentage of putatively pathogenic $V$. parahaemolyticus and $V$. cholerae isolates detected here indicates that these species do not constitute a significant health risk at recreational beaches of the German North Sea. Interestingly, however, all trh- and Kanagawa-positive strains were isolated from sediment samples. Organisms that are able to persist in sediment biofilms will more likely be able to colonize other tissues such as skin or the intestinal tract [73]; thus, the role of sediments in putting forth pathogenic clones could be an interesting aspect for future investigations.

Although putative virulence genes of $V$. vulnificus were not considered in this study, the mere presence of $V$. vulnificus should be viewed with concern. The potential health risk by this organism needs to be properly determined, especially during the summertime. The haemolysis gene $v v h$ has been associated with a large proportion of $V$. vulnificus isolates in Northern European Waters [37, 39] and was even used as a species-specific marker [74], suggesting that environmental $V$. vulnificus isolates inherently carry haemolysis genes. Despite this, $V$. vulnificus is generally not very virulent; however, it has an exceptional toxicity with $30 \%$ of wound infections ending in fatalities [4]. Common surveillance practices cannot accurately monitor the potential health risk emanating from $V$. vulnificus because the species does not correlate with faecal indicators (data not shown) and can occur at sites with excellent water quality [75].

In conclusion, non-virulent $V$. alginolyticus and $V$. parahaemolyticus are ubiquitously and perennially distributed in water and sediment at recreational beaches of the German North Sea, while the putative pathogen $V$. vulnificus frequently occurs in the estuaries of the rivers Ems and Weser at summertime. V. alginolyticus, V. parahaemolyticus and $V$. vulnificus exhibited distinct seasonal cycles, with water temperature being the crucial factor governing the presence and abundance of all three species. Minor additional effects of salinity, wind direction and rainfall were detected. The response of $V$. alginolyticus, $V$. parahaemolyticus and $V$. vulnificus to water temperature was shown to be species-specific with a particularly good adaptation of $V$. alginolyticus to temperatures around the freezing point, and an enormous increase in the probability of $V$. vulnificus presence with minor temperature increments at water temperatures $>20^{\circ} \mathrm{C}$. Vibrio spp. were not only more frequently isolated from sediments than from water, but also their abundance was generally one to three orders of magnitude higher in the benthic environment. In addition, the sediments were shown to have a protective effect on $V$. alginolyticus and particularly $V$. parahaemolyticus during the wintertime, suggesting an important role of sediments for Vibrio ecology in this dynamic temperate environment. Future studies will need to clarify the extent to which climate change may alter the composition of the Vibrio community in the Central Wadden Sea (particularly with regard to $V$. vulnificus), and whether climate change could favour the emergence and spreading of virulent representatives.

Acknowledgments This study was conducted within the German research programme KLIWAS, financed by the Federal Ministry of Transport, Building and Urban affairs. Work at the NLGA was further financially supported by the federal state of Lower Saxony. PCR analyses were performed throughout the German zoonose research network VibrioNet, financed by the Federal Ministry of Education and Research. The National Meterological Service supported our study with provision of weather data. The salinity chart (Fig. 1) was provided by Dr. Uwe Brockmann and Monika Schütt (University of Hamburg). Without the invaluable help of our colleagues at the local health authorities of the administrative districts Aurich, Leer and Cuxhaven, the study would not have been possible. Holger Weigelt and Julia Bachtin are greatly acknowledged for technical assistance with Vibrio and grain size analyses, respectively. Further thanks go to Enoma O. Omoregie for proofreading the manuscript and to two anonymous reviewers for helpful comments and suggestions for improvement.

\section{References}

1. Chakraborty S, Nair GB, Shinoda S (1997) Pathogenic vibrios in the natural aquatic environment. Rev Environ Health 12:63-80

2. Lee WC, Lee MJ, Kom JS, Park SY (2001) Foodborne illness outbreaks in Korea and Japan studies retrospectively. J Food Prot 64:899-902

3. Su HP, Chiu SI, Tsai JL, Lee CL, Pan TM (2005) Bacterial foodborne illness outbreaks in northern Taiwan, 1995-2001. J Infect Chemother 11(3):146-151

4. Oliver JD (2005) Vibrio vulnificus. In: Belkin S, Colwell RR (eds) Oceans and health: pathogens in the marine environment. Springer, New York, pp 253-276

5. Melhus A, Holmdahl T, Tjernberg I (1995) First documented case of bacteremia with Vibrio vulnificus in Sweden. Scand J Infect Dis 27(1):81-82

6. Høi L, Larsen JL, Dalsgaard I, Dalsgaard A (1998) Occurrence of Vibrio vulnificus biotypes in Danish marine environments. Appl Environ Microbiol 64(1):7-13

7. Torres L, Escobar S, López AI, Marco ML, Pobo V (2002) Wound infection due to Vibrio vulnificus in Spain. Eur J Clin Microbiol Infect Dis 21:537-538 
8. Schmidt U, Chmel H, Cobbs C (1979) Vibrio alginolyticus infections in humans. J Clin Microbiol 10(5):666-668

9. Schets FM, van den Berg HH, Demeulmeester AA, van Dijk E, Rutjes SA, van Hooijdonk HJ, de Roda Husman AM (2006) Vibrio alginolyticus infections in the Netherlands after swimming in the North Sea. Euro Surveill 11(45):3077

10. Sganga G, Cozza V, Spanu T, Spada PL, Fadda G (2009) Global climate change and wound care: case study of an off-season Vibrio alginolyticus infection in a healthy man. Ostomy Wound Mange 55(4):60-62

11. Pruzzo C, Huq A, Colwell RR, Donelli G (2005) Pathogenic Vibrio species in the marine and estuarine environment. In: Belkin $\mathrm{S}$, Colwell RR (eds) Oceans and health: pathogens in the marine environment. Springer, New York, pp 217-252

12. Kaneko T, Colwell RR (1973) Ecology of Vibrio parahaemolyticus in Chesapeake Bay. J Bacteriol 113(1):24-32

13. Motes ML, DePaola A, Cook DW, Veazey JE, Hunsucker JC, Garthright WE, Blodgett RJ, Chirtel SJ (1998) Influence of water temperature and salinity on Vibrio vulnificus in Northern Gulf and Atlantic Coast Oysters (Crassostrea virginica). Appl Environ Microbiol 64(4):1459-1465

14. Randa MA, Polz MF, Lim E (2004) Effects of temperature and salinity on Vibrio vulnificus population dynamics as assessed by quantitative PCR. Appl Environ Microbiol 70(9):5469-5476

15. Hsieh JL, Fries JS, Noble RT (2008) Dynamics and predictive modelling of Vibrio spp. in the Neuse River Estuary, North Carolina, USA. Environ Microbiol 10(1):57-64

16. Martinez-Urtaza J, Lozano-Leon A, Varela-Pet J, Trinanes J, Pazos Y, Garcia-Martin O (2008) Environmental determinants of the occurrence and distribution of Vibrio parahaemolyticus in the Rias of Galicia, Spain. Appl Environ Microbiol 74(1):265-274

17. Oberbeckmann S, Wichels A, Wiltshire KH, Gerdts G (2011) Occurrence of Vibrio parahaemolyticus and Vibrio alginolyticus in the German Bight over a seasonal cycle. Antonie van Leeuwenhoek 100:291-307

18. Tamplin ML, Gauzens AL, Huq A, Sack DA, Colwell RR (1990) Attachment of Vibrio cholerae serogroup O1 to zooplankton and phytoplankton of Bangladesh waters. Appl Environ Microbiol 56(6):1977-1980

19. Turner JW, Good B, Cole D, Lipp EK (2009) Plankton composition and environmental factors contribute to Vibrio seasonality. ISME J 3:1082-1092

20. Bock T, Christensen CN, Eriksen NH, Winter S, Rygaard H, Jörgensen F (1994) The first fatal case of Vibrio vulnificus infection in Denmark. APMIS 104:874-875

21. Dalsgaard A, Fridmodt-Møller N, Bruun B, Høi L, Larsen JL (1996) Clinical manifestations and molecular epidemiology of Vibrio vulnificus infections in Denmark. Eur J Clin Microbiol Infect Dis 15(3):227-232

22. Andersson Y, Ekdahl K (2006) Wound infections due to Vibrio cholerae in Sweden after swimming in the Baltic Sea, summer 2006. Euro Surveill 11(8):3013

23. Lukinmaa S, Mattila K, Lehtinen V, Hakkinen M, Koskela M, Siitonen A (2006) Territorial waters of the Baltic Sea as a source of infections caused by Vibrio cholerae non-O1, non-O139: report of 3 hospitalized cases. Diagn Microbiol Infect Dis 54:1-6

24. Frank C, Littman M, Alpers K, Hallauer J (2006) Vibrio vulnificus wound infections after contact with the Baltic Sea, Germany. Euro Surveill 11(8):3024

25. Mertens A, Nagler J, Hansen W, Gepts-Friedenreich E (1979) Halophilic, lactose-positive Vibrio in a case of fatal septicemia. J Clin Microbiol 9:233-235

26. Reilly GD, Reilly CA, Smith EG, Baker-Austin C (2011) Vibrio alginolyticus-associated wound infection acquired in British waters, Guernsey, July 2011. Euro Surveill 16(42):10
27. Baker-Austin C, Trinanes JA, Taylor NGH, Hartnell R, Siitonen A, Martinez-Urtaza J (2012) Emerging Vibrio risk at high latitudes in response to ocean warming. Nat Clim Chang. doi:10.1038/ nclimate 1628

28. Belkin IM (2009) Rapid warming of large marine ecosystems. Prog Oceanogr 81:207-213

29. MacKenzie BR, Schiedek D (2007) Daily ocean monitoring since the 1860 s shows record warming of northern European seas. Global Change Biol 13(7):1335-1347

30. Wiltshire KH, Malzahn AM, Wirtz K, Greve W, Janisch S, Mangelsdorf P, Manly BFJ, Boersma M (2008) Resilience of North Sea phytoplankton spring bloom dynamics: an analysis of long-term data at Helgoland Roads. Limnol Oceanogr 53(4):1294 1302

31. Vezzulli L, Brettox I, Pezzati E, Reid PC, Colwell RR, Höfle MG, Pruzzo C (2012) Long-term effects of ocean warming on the prokaryotic community: evidence from the vibrios. ISME J 6:2130

32. Bauer A, Ostensvik O, Florvag M, Ormen O, Rørvik LM (2006) Occurrence of Vibrio parahaemolyticus, V. cholerae, and V. vulnificus in Norwegian Blue Mussels (Mytilus edulis). Appl Environ Microbiol 72(4):3058-3061

33. Eiler A, Johansson M, Bertilsson S (2006) Environmental infuences on Vibrio populations in northern temperate and boreal coastal waters (Baltic and Skagerrak Seas). Appl Environ Microbiol 72(9):6004-6011

34. Lhafi SK, Kühne M (2007) Occurrence of Vibrio spp. in blue mussels (Mytilus edulis) from the German Wadden Sea. Int $\mathrm{J}$ Food Microb 116(2):297-300

35. Ellingsen AB, Rørvik LM (2008) Occurrence of potentially pathogenic Vibrio spp. in Norwegian seawater. In: Ellingsen AB (ed) Vibrio parahaemolyticus, $V$. cholerae and $V$. vulnificus in Norway, with special attention to $V$. parahaemolyticus. Dissertation, Norwegian School of Veterinary Science

36. Schets FM, van den Berg HHJL, Marchese A, Garbom S, de Roda Husman AM (2011) Potentially human pathogenic vibrios in marine and fresh bathing waters related to environmental conditions and disease outcome. Int J Hyg Envir Health 214(5):399-406

37. Collin B, Rehnstam-Holm AS (2011) Occurrence and potential pathogenesis of Vibrio cholerae, Vibrio parahaemolyticus and Vibrio vulnificus on the South Coast of Sweden. FEMS Microbiol Ecol 78:306-313

38. Bockemühl J, Roch K, Wohlers B, Aleksic V, Aleksic S, Wokatsch R (1986) Seasonal distribution of facultatively enteropathogenic vibrios (Vibrio cholerae, Vibrio mimicus, Vibrio parahaemolyticus) in the freshwater of the Elbe river at Hamburg. J Appl Bacteriol 60:435-442

39. Hervio-Heath D, Colwell RR, Derrien A, Robert-Pillot A, Fournier JM, Pommepuy M (2002) Occurrence of pathogenic vibrios in coastal areas of France. J Appl Microbiol 92:1123-1135

40. Vezzulli L, Pezzati E, Moreno M, Fabiano M, Pane L, Pruzzo C, The VibrioSea Consortium (2009) Benthic ecology of Vibrio spp. and pathogenic Vibrio species in a coastal Mediterranean environment (La Spezia Gulf, Italy). Microb Ecol 58(4):208-818

41. Anonymous (2006) ISO 19458:2006-12. Water quality-sampling for microbiological analysis. International Organization for Standardization, Geneva

42. Oberbeckmann S, Wichels A, Maier T, Kostrzewa M, Raffelberg M, Raffelberg S, Gerdts G (2011) A polyphasic approach for the differentiation of environmental Vibrio isolates from temperate waters. FEMS Microbiol Ecol 75:145-162

43. Bauer A, Rørvik L (2007) A novel multiplex PCR for the identification of Vibrio parahaemolyticus, Vibrio cholerae and Vibrio vulnificus. Lett Appl Microbiol 45:371-375

44. Di Pinto A, Ciccarese G, Tantillo G, Catalano D, Forte VT (2005) A collagenase-targeted multiplex PCR assay for identification of Vibrio 
alginolyticus, Vibrio cholerae, and Vibrio parahaemolyticus. J Food Protect 68(1):150-153 (4)

45. Tada J, Ohashi T, Nishimura N, Shirasaki Y, Ozaki H, Fukushima S, Takano J, Nishibuchi M, Takeda Y (1992) Detection of the thermostable direct hemolysin gene $(t d h)$ and the thermostable direct hemolysin-related hemolysin gene (trh) of Vibrio parahaemolyticus by polymerase chain-reaction. Mol Cell Probes 6:477-487

46. Nandi B, Nandi RK, Mukhopadhyay S, Nair GB, Shimada T, Ghose AC (2000) Rapid detection of species-specific identification of Vibrio cholerae using primers targeted to the gene of outer membrane protein ompW. J Clin Microbiol 38:4145-4151

47. Mantri CK, Mohapatra SS, Ramamurthy T, Ghosh R, Colwell RR, Singh DV (2006) Septaplex PCR assay for rapid identification of Vibrio cholerae including detection of virulence and int SXT genes. FEMS Microbiol Lett 265:208-214

48. Mohr CF (1856) Neue massanalytische Bestimmung des Chlors in Verbindungen. Ann Chem Pharm 97(3):335-338

49. Anonymous (1985) DIN 38405-1: 1985-12. German standard methods for the examination of water, waste water and sludge; anions (group D); determination of chloride ions (D 1). Deutsches Institut für Normung e.V, Berlin

50. Knudsen M (1901) Hydrographical tables. G.E.C. Gad, Copenhagen, $\mathrm{p} 63$

51. Anonymous (2001) DIN EN 13137:2001-12. Characterization of waste-determination of total organic carbon (TOC) in waste, sludges and sediments. European Committee for Standardization, Brussels, German version

52. Ackermann F (1980) A procedure for correcting the grain size effect in heavy metal analyses of estuarine and coastal sediments. Environ Technol Lett 1:518-527

53. Figge K, Köster R, Thiel H, Wieland P (1980) Schlickuntersuchungen im Wattenmeer der Deutschen Bucht. Zwischenbericht über ein Forschungsprojekt der KFKI. Die Küste 35:187-204

54. Dick S, Kleine E et al. (2008) A new operational circulation model for the North Sea and the Baltic using a novel vertical co-ordinatesetup and first results. Fifth International Conference on EuroGOOS, Exeter, EuroGOOS

55. Dick S, Müller-Navarra S (2002) An operational oil spill model for the North Sea and the Baltic - model features and applications. Third R\&D Forum on High-Density Oil Spill Response, Brest, IMO

56. Van Landuyt HW, Van Hulle BMC, Fossepre JM, Verschraegen G (1985) The occurrence of Vibrio spp. at the Belgian coast. Acta Clin Belg 40:12-16

57. Veenstra J, Rietra PJG, Coster JM, Slaats E, Dirks-Go S (1994) Seasonal variations in the occurrence of Vibrio vulnificus along the Dutch coast. Epidemiol Infect 112:285-290

58. Ayres PA, Barrow GI (1978) The distribution of Vibrio parahaemolyticus in British coastal waters: report of a collaborative study. J Hyg 80:281-294

59. Singleton FL, Attwell R, Jangi S, Colwell RR (1982) Effects of temperature and salinity on Vibrio cholerae growth. Appl Environ Microbiol 44(5):1047-1058
60. Kaneko T, Colwell RR (1978) The annual cycle of V.parahaemolyticus in Chesapeake Bay. Microb Ecol 4:135-155

61. Tantillo GM, Fontanarosa M, Di Pinto A, Musti M (2004) Updated perspectives on emerging vibrios associated with human infections. Lett Appl Microbiol 39:117-126

62. Oliver JD (2010) Recent findings on the viable but nonculturable state in pathogenic bacteria. FEMS Microbiol Rev 34(4):415-425

63. Baross J, Liston J (1970) Occurrence of V. parahaemolyticus and related haemolytic vibrios in marine environments of Washington State. Appl Microbiol 20(2):179-186

64. Blackwell KD, Oliver JD (2008) The ecology of V. vulnificus, Vibrio cholerae, and Vibrio parahaemolyticus in North Carolina estuaries. J Microbiol 46(2):146-153

65. Thompson JR, Polz MF (2006) Dynamics of Vibrio populations and their role in environmental nutrient cycling. In: Thompson FL, Austin B, Swings J (eds) The biology of vibrios. ASM Press, Washington, DC, pp 190-203

66. Sherr E, Sherr B (2000) Marine microbes: an overview. In: Kirchman DL (ed) Microbial ecology of the oceans. Wiley, London, pp 13-46

67. Martinez-Urtaza J, Bowers JC, Trinanes J, DePaola A (2010) Climate anomalies and the increasing risk of Vibrio parahaemolyticus and Vibrio vulnificus illnesses. Food Research International, pp. 1780-1790

68. Baker-Austin C, Stockley L, Rangdale R, Martinez-Urtaza J (2010) Environmental occurrence and clinical impact of Vibrio vulnificus and Vibrio parahaemolyticus: a European perspective. Environ Microbiol Rep 2(1):7-18

69. Robert-Pillot A, Guénolé A, Lesne J, Delesmont R, Fournier JM, Quilici ML (2004) Occurrence of the $t d h$ and $t r h$ genes in Vibrio parahaemolyticus isolates from waters and raw shellfish collected in two French coastal areas and from seafood imported into France. Int J Food Microbiol 91(3):319-325

70. Ellingen AB, Jørgensen WS, Monshaugen M, Rørvik LM (2008) Genetic diversity among Norwegian Vibrio parahaemolyticus. J Appl Microbiol 105(6):2195-2202

71. Nishibuchi M, Kaper JB (1995) Thermostable direct hemolysin gene of Vibrio parahaemolyticus - a virulence gene aquired by a marine bacterium. Infect Immun 63:2093-2099

72. Caburlotto G, Gennari M, Ghidini V, Tafi MC, Lleo MM (2009) Presence of T3SS2 and other virulence-related genes in $t d h$-negative Vibrio parahaemolyticus environmental strains isolated from marine samples in the area of the Venetian Lagoon, Italy. FEMS Microbiol Ecol 70(3):506-514

73. Pruzzo C, Vezzulli L, Colwell RR (2008) Global impact of Vibrio cholerae interactions with chitin. Environ Microbiol 10(6):1400-1410

74. Han F, Ge B (2010) Multiplex PCR assays for simultaneous detection and characterization of Vibrio vulnificus strains. Lett Appl Microbiol 51(2):234-240

75. Anonymous (2006) Directive 2006/7/EC of the European Parliament and of the Council of 15 February 2006 concerning the management of bathing water quality and repealing Directive 76/160/EEC. Off J Eur Union L 64:37-51, 4.3.2006 